\title{
Website Appeal: Development of an Assessment Tool and Evaluation Framework of E-Marketing
}

\author{
Salam Abdallah ${ }^{1}$ and Bushra Jaleel ${ }^{2}$ \\ ${ }^{1}$ Abu Dhabi University, College of Business Administration, Al Ain, UAE, salam.abdallah@adu.ac.ae \\ ${ }^{2}$ Abu Dhabi University, College of Business Administration, AI Ain, UAE, bushra.jaleel@adu.ac.ae
}

Received 6 February 2014; received in revised form 28 October 2014; accepted 29 October 2014

\begin{abstract}
The aim of this study is twofold; firstly, to develop a comprehensive measure that quantitatively assesses an e-store's web appeal, and secondly, to propose a framework that evaluates effectiveness of online marketing efforts in terms of overall appeal of e-tailing sites. The paper adopts a hybrid approach to website assessment which involves studying both information system elements and dimensions of e-marketing to define and measure the concept of web appeal. A total of five information system elements and seven e-marketing elements were identified as essential components of web appeal, and were used to build a measurement instrument. The instrument's validity was confirmed by testing it across 80 e-stores in the Middle East and its usefulness with respect to the identification of an e-store's strengths and weaknesses was established. In addition to being a measure of overall web appeal, the instrument also contributes towards conceptualization of a theoretically sound framework that aligns elements of web appeal to e-marketing objectives. This model provides a systematic criteria for comparing websites, and offers valuable insights into how website attributes can be used to achieve desired performance in terms of attracting, engaging, and retaining customers, as well as competing with rival stores.
\end{abstract}

Keywords: Website appeal, E-marketing, Website evaluation, E-tailing, E-commerce, Web design 


\section{Introduction}

One of the most profound consequences of the information revolution has been the ability of firms and individuals to conduct businesses over electronic networks, leading to the advent of e-commerce. Since its inception in the 1970s, e-commerce has seen unprecedented growth across the world, most of which is attributed to the increasing proliferation of electronic retailers (e-tailers). Much like their physical counterparts, e-tailers consider marketing as a prime business function, and make use of it extensively to support their growth. With rising competition and an expanding consumer base, effective online marketing strategies are becoming critical to the success of e-tailers. However, while the ubiquitous significance of marketing has laid a firm theoretical foundation for the traditional brickand- mortar industry, literature on marketing principles for click-and- order firms is relatively less comprehensive.

Since selling and purchasing over the internet carries distinct characteristics [27], [33], [63], [127] traditional marketing models, developed specifically to support offline marketing, cannot be used to fully explain and assess marketing efforts of firms trading online [45], [53]. Consequently, a significant amount of work has been done to either extend established marketing models to include elements of digital marketing [23] or build new theoretical paradigms [68] to assess and evaluate marketing over the web. With the exception of a few [26], [109], [125], researchers have concurred that the effectiveness of marketing efforts of firms trading online should be assessed by evaluating their websites [32], [79], [82], [87], [91]. This is because, for e-tailers, a website is not just a platform for digitally representing the company and its products or services; rather, it serves as the prime mode of revenue generation, and is the main (if not the sole) contact point between the buyer and the seller.

A common theme of research work in this area has been to identify website attributes that positively reinforce consumer purchase decisions [6], [31], [89], [100]. A review of literature reveals that contributions to this body of knowledge, albeit extensive, are disproportionate; whereby some attributes (such as usability [38], [48], [77], information content [20], [34], [43], credibility [44], [66], [71], etc.) have been studied recurrently, while others have not received much attention. One such attribute is website appeal. Users make lasting judgments about a website's appeal in less than a second of seeing it for the first time [103], and these first impressions are strong enough to later influence the website's perceived usability and trustworthiness [75]. Yet the concept of website appeal has not received much attention from a theoretical stand point.

Deriving from the ideas of Bonnardel et al. [12], website appeal can be defined as the degree to which a website is perceived as pleasing, engaging, and appropriate by the consumer. Given that attracting and engaging customers are prime concerns of marketing, it is surprising that virtually no studies link the concept of website appeal with emarketing effectiveness. Instead, much of the contemporary literature on e-marketing assesses it as a transaction medium [16], [36] or a communication tool [110], [113] in order to determine the success of marketing efforts over the web. Despite the empirical validity of their findings, the scope of these studies do not allow them to identify whether customers find the website as pleasant, engaging, or a good-enough point of contact. This paper intends to fill this gap in literature by exploring this concept in more detail and proposing an evaluation tool to assess user perceptions of a website's overall appeal.

\subsection{Research Purpose and Significance}

The purpose of this paper is to help theorists and practitioners gather consumer perceptions of an e-store's overall appeal, thereby quantitatively evaluating the store's marketing efforts over the web. This is done by first identifying key elements that reliably represent components of web appeal on e-tailing sites, and then developing a tool that uses these elements to assess e-marketing effectiveness of online stores. The paper will also make a theoretical contribution in this field by developing a framework that conceptualizes how a website's appeal contributes to achievement of e-marketing objectives. More specifically, the study aims to:

1. Develop an evaluation instrument to assess an e-store's website appeal;

2. Demonstrate the usefulness of the instrument by applying it on a sample of websites; and

3. Provide a conceptual framework that aligns the major elements of website appeal to an e-store's online marketing objectives

Essentially, by studying existing models and observing current practices of e-tailing sites, this paper aims to explore the concept of website appeal in more detail, and presents a conceptual model to assess and compare overall appeal of e-tailing sites. Owing to the significant investments made in developing and running online stores, e-tailing sites are expected to generate significant value and require continuous evaluation to assess their effectiveness [81]. A major contribution of this paper is to both theory and practice, it addresses the lack of actionable metrics that can assess performance of e-marketing efforts, which is one of the biggest challenges faced by digital marketers [72], [104]. 
Moreover, not many studies have attempted to explore the concept of a website's persuasive capacity [39], [95]; even fewer have scrutinized the concept of overall website appeal, signifying an apparent gap in this body of work. From a theoretical stand point, this paper adds to existing literature by extending the concept of website persuasiveness and appeal beyond aesthetic elements and providing new avenues for research in this field. A clear benefit of adopting such a holistic approach to studying website appeal and linking it to online marketing is that it will enable e-tailers to not just attract new customers but also better engage and retain their existing customers. By establishing this linking, the research also suggests ways for targeted decision making to aid in the achievement of select e-marketing objectives.

In the following sections, a review of the literature is presented which forms the basis of the theoretical framework described next. The paper proceeds by summarizing the methodology used to build and test the instrument, followed by an illustration of how this tool can be used to assess website performance and relate overall web appeal to emarketing objectives. The results of this study are then compared with the findings documented in literature, and limitations of this study are presented with recommendations for future research. The paper concludes with a discussion of this study's contributions, and the implications it holds for e-marketers and website design practitioners.

\section{Literature Review}

This section summarizes the findings of published literature in order to develop a concise definition of website appeal, and to assess the influence of modern marketing frameworks on the evaluation of e-commerce websites.

\subsection{Website Appeal}

Website appeal refers to the quality of a website's perceptual features to generate user interaction [12], and persuade online shoppers towards a site [11]. An appealing website is more likely to attract visitors, stimulate positive purchase intentions, and establish higher standards of trust and usability [28], [75], [94], [122], [128]. Wang and Liu [126] relate website appeal to enjoyment and suggest that a website with appealing features would lead to repeat visits. While research work focusing on this particular construct is scant, its usefulness, as an attribute that influences consumer perceptions, is well established [4], [65] especially in the context of creating a good first impression. Perhaps one of the most cited publications in this regard is that of Lindgaard et al., [76] who note that users formulate their first impression of a website in less than 50 milliseconds. Studies have also found that a website's first impression has long term implications on how a site's usability and credibility is perceived by the users [75], as well as the consumer's intention to purchase [37], [103].

Although these authors discuss the significance of website appeal and present different ways to create a good first impression, not enough is said about how this first impression can be translated into a lasting one. As Reibstein [102] notes, the website dimensions that attract users to a website are not the same as the dimensions critical to retain the customers on the website in the long run. Moreover, most of these studies have operationalized the concept of appeal strictly in terms of the visual quality and aesthetic elements of the website. For instance, Reinecke et al., [103] quantifies website appeal in terms of visual complexity and colorfulness, and establishes that the aesthetic components of a website are decisive in engaging users online. Aesthetic elements have also been linked to website usability [28], [50], [70], [119], [121] credibility [62], web page preferences [105], [118] and behavioral intentions [46], [122].

All in all, despite the technical relevance and theoretical importance of these findings, this body of literature has two main shortcomings. Firstly, regardless of the significance of aesthetics as an important design parameter for evaluating effectiveness of websites [17], it cannot be considered as the sole dimension defining website appeal. Numerous authors have suggested that a website's appeal goes beyond its aesthetic elements [10], [103], yet neither has the concept been formally studied, nor has it been comprehensively measured. Secondly, existing research work on the appeal of online stores appears to give very less attention to the, clearly intuitive, role of marketing in attracting and engaging customers.

Even though virtually no studies explicitly relate website appeal to e-marketing effectiveness, such a relationship can certainly be deduced. Firstly because a major aim of e-marketing is to get closer to the customers and grow sales [18], which can be better achieved when a website comprises appealing features [83]. Secondly, considering that customers make lasting judgments about a website's appeal in less than a second of seeing it for the very first time, an e-store's appeal plays an indispensable role in attracting and engaging customers [103], which brings it into the domain of e-marketing.

\subsection{E-Marketing and Consumer Orientation}

E-marketing has been defined in a variety of ways by members of the marketing community, and a lack of common vocabulary or frameworks pertinent to this field is widely acknowledged [61]. Quite generally, internet marketing can be defined as "the use of internet and other digital media to support marketing" [19]. As internet becomes commonplace, firms invest in digital marketing tools to benefit from reduced costs, wider coverage, better control, 
and other technological perks [120]. The concept of marketing has also evolved strictly on the theoretical front, whereby the previously seller dominated concept of traditional marketing has now widely acquired a more customer centric approach. This is one of the main reason why many authors do not consider the hallmark 4Ps [85] or 7Ps [13] marketing mix frameworks apt for assessing marketing efforts [25], [90], [99], [106]. This is especially true in the context of e-marketing where customers have become the starting point of marketing activities owing to their diverse needs, increased influence over each other, and rising control over the buying process [100].

One of the earliest contributions to modern marketing frameworks was the 4Cs marketing mix model presented by Lauterbom [69] in which each of the traditional 4 Ps was replaced by a consumer focused dimension; consumers' wants and needs replaced product; cost to satisfy needs replaced price; convenience replaced place; and communication replaced promotion. Consumer orientation was also emphasized in the Digital Marketing Framework [64], where success of online marketing efforts is defined using five key factors. These factors are termed as: attracting users, engaging users, creating interest in users, retaining users, and learning about the users to continuously customize the online approach.

While these models provide a consumer oriented perspective towards any digital marketing activity, some models have been proposed especially for e-commerce firms. For instance, Jaworski and Rayport [59] have developed the 7 Cs Framework that provides a set of standardized design principles for e-commerce websites. The seven elements in this framework are: context, which deals with the website's layout and overall design; content, which focuses on textual and visual information on the website; community, that is defined by the level of interactivity possible between two customers; customization, which is concerned with the site's ability to tailor itself according to user requirements; communication, which assesses the user-to-vendor communication tools available on the website; connection, which is concerned with the degree of association the website has with other sites; and lastly, commerce, the element which evaluates the site's ability to conduct commercial transactions over the web.

Similarly, the Web Marketing Mix Model [25] is a framework developed specifically for business-to-consumer (B2C) marketing activities over the web. Also known as the 4S framework (scope, site, synergy, and system), this model emphasizes integrating a firm's online and offline strategies to develop comprehensive marketing plans for the digital environment. More recently, Kucuk [68] has presented four e-marketing value drivers, namely; connectivity, content, community, and commitment, as a $4 \mathrm{Cs}$ framework for online marketing.

Yet another school of thought that persists in literature is of those authors who have reengineered the traditional marketing mix model to incorporate new dimensions instead of replacing the 4Ps altogether. Typically, these frameworks adapt the dimensions proposed by the product [85] and service [13] marketing mix models to meet the ever evolving requirements of e-marketing activities, thereby acquiring the focus on customer orientation and digital marketing principals, whilst maintaining the simplicity and clarity of the traditional frameworks. A case in point is the extension of the traditional marketing mix model to form the 4Ps + P2C2S3 model [61]. Here, the 4Ps are adapted from the traditional marketing mix, while several other elements (personalization, privacy, customer service, community, site, security, and sales promotion) are added to more comprehensively reflect the different dimensions of the digital environment.

One of the most comprehensive adaptations of the 7Ps services mix is the one proposed by Chaffey and Smith [18]. Owing to the intangibility of websites and the digital features they support, the authors adapt the 7Ps of marketing to fit a website's content, such that all of the $7 \mathrm{Ps}$ are redefined to incorporate digital marketing elements. In addition, they also recommend the use of an eighth $\mathrm{P}$, partnerships, in the e-marketing framework in order to reflect the external affiliations of e-commerce firms. This is in line with the recommendations of studies which note that an integration of marketing and public relation (PR) communication messages is expected [67] and often seen on websites [14]

All of these frameworks have provided unique contributions towards assessing and explaining e-marketing efforts. A common theme, however, underlying these frameworks is the importance of customer orientation and the need to incorporate the elements of digital technology to achieve marketing ends. Since building lasting customer relationship is widely considered as a key marketing philosophy [1], [21], [131] e-marketing cannot be studied without having customers at the forefront. Therefore, it is essential that any assessment framework that evaluates the marketing activities on e-tailing websites does so by adopting a customer perspective.

\subsection{Evaluating Websites}

Chiou et al. [22] investigated the trends in website evaluation over the past decade and noted that website assessment frameworks normally follow an information systems (IS) approach, a marketing approach, or a combined approach. An IS approach focuses on assessing technology-oriented aspects of the websites, such as the usability, navigability, or information quality; thereby providing a measure for the technical prowess of the site's developer. On the other hand, proponents of the marketing approach lay emphasis on factors such as advertisements, online transactions and customer service. The combined framework is a mixture of these two approaches which, the authors note, has recently received much more attention in comparison to the other approaches, possibly due to the increasing need to incorporate vendor and consumer perspective in website assessment models [47]. 
Website assessment and evaluation is a widely studied area and several quantitative and qualitative methodologies and frameworks have been presented in literature. Table 1 summarizes some of the evaluation models developed mainly for assessing e-commerce websites.

\section{Table 1: Website assessment models}

\begin{tabular}{|c|c|c|c|}
\hline Model & Description & Industry & Source \\
\hline $\begin{array}{l}\text { Extended Model Of } \\
\text { Internet Commerce } \\
\text { Adoption (eMICA) }\end{array}$ & $\begin{array}{l}\text { A model that classifies e-commerce application } \\
\text { development into three stages (web-based promotion, } \\
\text { provision of information and services, and transaction } \\
\text { processing) and helps identify which stage a business is at }\end{array}$ & $\begin{array}{l}\text { Travel and } \\
\text { Tourism }\end{array}$ & $\begin{array}{l}{[15],} \\
{[74]}\end{array}$ \\
\hline SITEQUAL & $\begin{array}{l}\text { An instrument to measure perceived quality of an internet } \\
\text { shopping site in terms of ease of use, aesthetic design, } \\
\text { processing speed, and security }\end{array}$ & $\begin{array}{l}\text { Internet } \\
\text { shopping } \\
\text { sites }\end{array}$ & [133] \\
\hline E-SEQUAL & $\begin{array}{l}\text { A model that integrates customers' perceived dimensions } \\
\text { of service quality into the design and evaluation of e- } \\
\text { commerce }\end{array}$ & $\begin{array}{l}\text { E-commerce } \\
\text { firms }\end{array}$ & [97] \\
\hline $\begin{array}{l}\text { Microsoft Usability } \\
\text { Guidelines (MUG) } \\
\text { Modified For B2C } \\
\text { Firms }\end{array}$ & $\begin{array}{l}\text { A five-attribute measure of website appeal based on: } \\
\text { content quality, ease of use, technology request, made for } \\
\text { the medium content, and emotional response }\end{array}$ & $\begin{array}{l}\text { Internet } \\
\text { shopping } \\
\text { sites }\end{array}$ & {$[126]$} \\
\hline $\begin{array}{l}\text { Culturally-Oriented } \\
\text { Website Usability } \\
\text { Evaluation }\end{array}$ & $\begin{array}{l}\text { A tool to assess website usability in the context of cultural } \\
\text { dimensions }\end{array}$ & $\begin{array}{l}\text { Government } \\
\text { websites }\end{array}$ & [123] \\
\hline $\begin{array}{l}\text { Strategic Framework } \\
\text { for Website } \\
\text { Evaluation }\end{array}$ & $\begin{array}{l}\text { An internal evaluation instrument to ensure consistency } \\
\text { between web strategy and actual website presence }\end{array}$ & $\begin{array}{l}\text { E-commerce } \\
\text { firms }\end{array}$ & [22] \\
\hline $\begin{array}{l}\text { Website Information } \\
\text { Content Survey }\end{array}$ & $\begin{array}{l}\text { A tool to systematically describe website information } \\
\text { content }\end{array}$ & $\begin{array}{l}\text { E-commerce } \\
\text { firms }\end{array}$ & [49] \\
\hline $\begin{array}{l}\text { Modified Balanced } \\
\text { Scorecard (mBSC) }\end{array}$ & $\begin{array}{l}\text { A model to assess website performance using overall } \\
\text { technical functionality, customer friendliness and usability, } \\
\text { effectiveness of destination marketing, and information } \\
\text { content }\end{array}$ & $\begin{array}{l}\text { Convention } \\
\text { and Visitor } \\
\text { Bureaus }\end{array}$ & [112] \\
\hline $\begin{array}{l}\text { The Hedonic- } \\
\text { Utilitarian Dual } \\
\text { Mediation Hypothesis }\end{array}$ & $\begin{array}{l}\text { A conceptual model to understand individual behavior in an } \\
\text { online environment using attributes of cognition and } \\
\text { emotions }\end{array}$ & $\begin{array}{l}\text { Travel and } \\
\text { Tourism }\end{array}$ & [81] \\
\hline $\begin{array}{l}\text { Effectiveness } \\
\text { Evaluation Model }\end{array}$ & $\begin{array}{l}\text { A model based on the marketing mix (product, price, place, } \\
\text { and promotion) and website quality (reliability, } \\
\text { responsiveness, credibility, currency, relevance, } \\
\text { personalization, navigability, and security) elements }\end{array}$ & $\begin{array}{l}\text { Travel and } \\
\text { Tourism }\end{array}$ & [117] \\
\hline $\begin{array}{l}\text { Formative } \\
\text { Measurement of } \\
\text { Website Performance }\end{array}$ & $\begin{array}{l}\text { A website performance measure comprising eight } \\
\text { dimensions: system availability, ease of use, usefulness, } \\
\text { navigational challenge, website design, content quality, } \\
\text { trust, and enjoyment }\end{array}$ & $\begin{array}{l}\text { Travel and } \\
\text { Tourism }\end{array}$ & [33] \\
\hline $\begin{array}{l}\text { Quality Evaluation } \\
\text { Model (QuEM) }\end{array}$ & $\begin{array}{l}\text { An assessment of website design characteristics defined in } \\
\text { terms of six parameters; usability, visual aspects, technical } \\
\text { adequacy, security, communication, and prestige }\end{array}$ & $\begin{array}{l}\text { Internet } \\
\text { shopping } \\
\text { sites }\end{array}$ & {$[17]$} \\
\hline $\begin{array}{l}\text { Cube Assessment } \\
\text { Framework }\end{array}$ & $\begin{array}{l}\text { A framework for assessing B2C websites using eight } \\
\text { assessment criteria: content, community, communication, } \\
\text { collaboration, connection, commerce, context, and } \\
\text { customization }\end{array}$ & $\begin{array}{l}\text { Internet } \\
\text { shopping } \\
\text { sites }\end{array}$ & {$[47]$} \\
\hline $\begin{array}{l}\text { Web Quality Index } \\
\text { (WQI) }\end{array}$ & $\begin{array}{l}\text { An integrated model to establish the quality and suitability } \\
\text { of websites using technical, communicative, relational, and } \\
\text { persuasive aspects of the website }\end{array}$ & $\begin{array}{l}\text { Travel and } \\
\text { Tourism }\end{array}$ & [39] \\
\hline $\begin{array}{l}\text { A Measurement Index } \\
\text { Common to Website } \\
\text { and Store Images }\end{array}$ & $\begin{array}{l}\text { A measurement index based on } 10 \text { channel dimensions of } \\
\text { site and store image: offering, price, layout, accessibility, } \\
\text { promotions, customer service, advice, reputation, } \\
\text { institution, and connections with other channels }\end{array}$ & $\begin{array}{l}\text { Websites } \\
\text { and physical } \\
\text { stores }\end{array}$ & [8] \\
\hline
\end{tabular}

While there is no standardized methodology in place to analyze e-tailing websites per se, especially in the context of overall appeal, several studies provide useful insights into developing a comprehensive framework. For instance, SITEQUAL [133] an instrument developed to measure perceived quality of an internet shopping site, uses nine elements that are categorized into four main dimensions; ease of use, aesthetic design, processing speed, and security. Although, it is considered as a widely accepted model for evaluating online service quality, its focus solely on website interface whilst discounting customer orientation and other e-marketing aspects, limits its applicability for assessing marketing effectiveness over the web. Petre et al. [97] addressed this concern by introducing customer 
perceived dimensions of service quality (E-SEQUAL) for evaluating e-commerce websites. The authors have assessed whether websites are able to meet or exceed customer expectations of value. In addition to service quality, website evaluation models that focus on information content [49] and design quality also exist [17]. However, despite the frameworks' focus on customer experiences and perspectives, the concept of overall website appeal remains out of their scope.

Wang and Liu [126] acknowledged the concept of appeal when attempting to assess usability of e-commerce websites. The authors used a modified version of Microsoft Usability Guidelines (MUG) by including five attributes of website appeal that increase site use, namely; content quality, ease of use, technology request, made for the medium content, and emotional response. However, the authors also noted that even though the instrument can be used to rank websites, it is not sufficiently focused on customer considerations. In contrast to these studies, a recent trend has been to adopt a strategic perspective towards evaluating websites. Some notable contributions in this area [22], [47] have provided frameworks that ensure internal consistency between a firm's web activities and marketing strategies. These models, although highly useful in their own respect, do not lend themselves to comprehensively assess online marketing efforts and compare competing e-tailing websites that follow different strategies. The extensive review of published literature reveals that existing measures of website evaluation either fail to prioritize customer orientation, overlook e-marketing objectives, or contradict each other. Thus, a commonly validated tool or model, seems nonexistent.

In an attempt to synthesize the diverse findings of many similar website evaluation models, Park and Gretzel [95] identified a total of nine factors that appeared to form the basis of the majority of studies. The authors termed these factors as; information quality, ease of use, responsiveness, security/privacy, visual appearance, trust, interactivity, personalization, and fulfillment. Based on how these factors are defined by the authors, it is clear that the list is a combination of both IS (information quality, ease of use, security/privacy, visual appearance, and trust), and marketing elements (responsiveness, interactivity, personalization, and fulfillment). Similarly, the effectiveness evaluation model [117] developed for the airline industry provides another illustration of the combined approach identified, applied, and recommended by many [22], [35], [78], [92], [97]. Based on these recommendations, it is believed that the basic marketing aspects and technical characteristics of a website cannot be viewed in isolation, and therefore, web attributes reflecting both marketing and IS features of websites are used to derive a theoretical framework for this study.

\section{Theoretical Framework}

The purpose of this study is to assess an e-tailing website's overall appeal in order to evaluate its e-marketing efforts. Appeal is defined here as the degree to which a website's marketing efforts are perceived as pleasing, appealing, and appropriate by the consumer [12]. It is believed that an appealing website should have the potential to translate a user's first impression of the website into a favorable lasting impression. Since both marketing and technical elements of the website contribute towards shaping the users' perception of appeal, a theoretical framework should represent both of these dimensions.

As stated previously, Park and Gretzel [95] and Tsai et al. [117] provide a representative set of factors that incorporate elements of IS and marketing functions. However, it is believed that while the IS elements identified by these studies sufficiently cover the technical aspects of a website; the marketing elements do not exhaustively incorporate all marketing attributes relevant to e-tailing sites. Therefore, the study derives the IS dimensions (hence forth referred to as general website elements) using the elements defined in these studies [95], [117], but the dimensions proposed by Chaffey and Smith [18] are used to derive the marketing mix elements, due to their comprehensive coverage of e-marketing attributes and relevance to online shopping websites. The operationalization of overall website appeal in terms of general website elements and marketing mix elements is depicted in Figure 1.

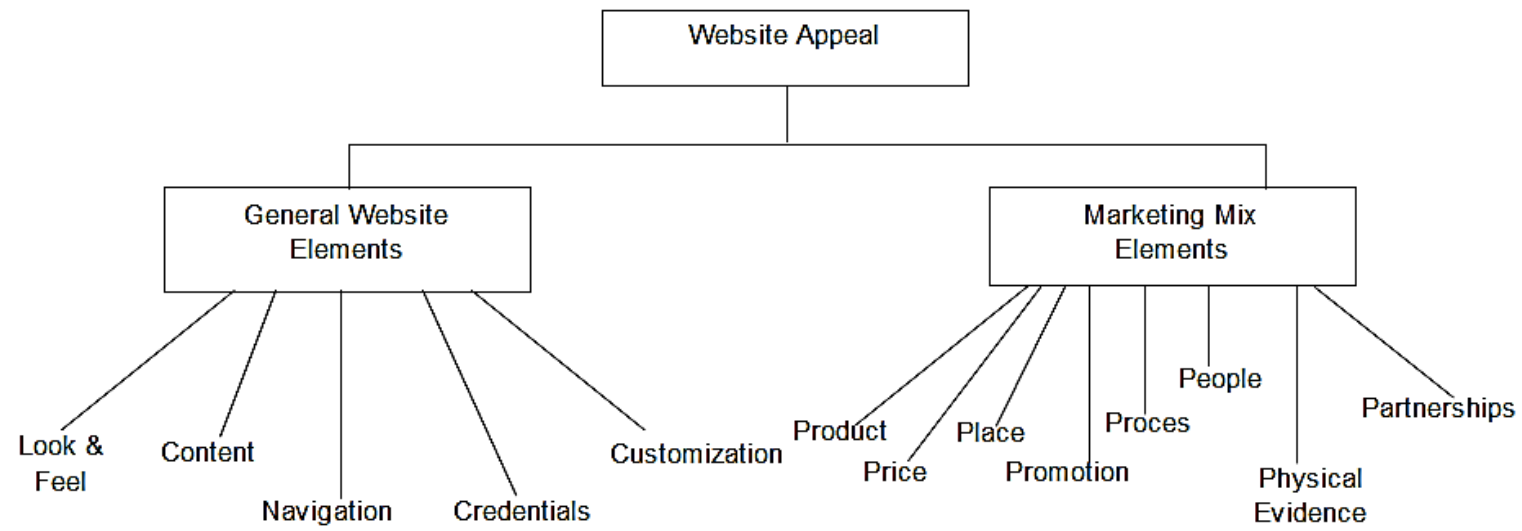

Figure 1: Website appeal in terms of e-marketing 
As shown in the figure, the General Website Elements are further classified in terms of six components. Look \& Feel focuses on the aesthetic appeal of a web page, its readability, and download time, as well as its compatibility with browser. Navigation ensures an intuitive flow throughout the website, where webpages are logically arranged, easy to use, and clearly defined. Navigation on a website may be assessed in terms of presence of a site map, performance of the search engine, internal links etc. Credentials emphasize the trustworthiness of a website's owner, as well as the reliability of the information available on the website. Content establishes the accuracy and validity of textual and visual information. Its evaluation determines if the information available on the website is complete, appropriate, accurate and regularly updated. Customization (or Personalization) features on a website enable users to modify page elements to fit their preferences.

The elements in the second set are those that can be attributed to a website's Marketing Mix. Marketing mix is a generic term that refers to the combination of tools used by a firm to accomplish its marketing objectives. On websites, the element of Product is assessed in terms of assortment, validity and sufficiency of product description, in addition to the availability of product upon request. The element of Price is evaluated on the basis of its competitiveness and negotiability, as well as the multiplicity of payment options. Place in the marketing mix normally refers to the distribution of the product. On websites, this element is measured in terms of delivery time and geographical coverage. Promotion, the element focusing on communication, implies an assessment of online advertisements, special offers, direct mails, member benefits, social networking options, etc. Websites' Processes are assessed in terms of adaptive design features as well as ease and timeliness of order confirmation. The element of People primarily assesses a website's customer support. Its evaluation is based on the quality and availability of online help and interactivity offered to connect with sales staff and other user groups. The term Physical Evidence refers to physical cues that support a customer's evaluation of intangible services. On websites, these cues may include brand name, overall online experience, corporate affiliations through logos, and other signs of an actual physical presence (e.g. office address, pictures of the headquarters, etc.). Partnerships or public relations on websites are assessed in terms of the nature and degree of environmental services, and external affiliations. Websites may denote this by documenting press releases, highlighting relations with sponsors, and dedicating specific pages for careers, accomplishments, etc. Table 2 provides a brief summary of these elements and their support in the literature.

Table 2: Dimensions of overall website appea

\begin{tabular}{|c|c|c|}
\hline Dimensions & Description & References \\
\hline \multicolumn{3}{|l|}{ Website Elements } \\
\hline Look and Feel & aesthetic appeal and visual quality & [17], [101], [103], [122], [130] \\
\hline Navigation & ease of use and intuitive flow throughout the website & [30], [80], [122], [124] \\
\hline Credentials & reliability and trustworthiness of site operations and content & [40], [86], [101], [116], [124] \\
\hline Content & accuracy and completeness of textual and visual information & [17], [58], [73], [101], [112] \\
\hline Customization & ability to personalize store offerings and information & [87], [111] \\
\hline \multicolumn{3}{|c|}{ Marketing Mix Elements } \\
\hline Product & assortment, description, and availability of the good/service & [18], [61], [111] \\
\hline Price & product prices and the available payment options & [18], [61], [83] \\
\hline Place & delivery time and geographical coverage & [18], [22], [24] \\
\hline Promotion & marketing communication: advertising, sales promotion, etc. & {$[18],[96]$} \\
\hline Process & adaptive design, ease, and timeliness of order confirmations & [16], [18], [19] \\
\hline People & community interaction, including online support from staff & [18], [87], [111] \\
\hline Physical Evidence & physical cues supporting a customer's evaluation of services & [7], [18] \\
\hline Partnerships & nature and degree of external affiliations or public relations & {$[14],[18]$} \\
\hline
\end{tabular}

These elements lay the foundation for developing an instrument to evaluate an e-tailing site's overall appeal. The next section elaborates the research method employed for developing and testing this instrument, as well as description on how data was analyzed and processed to meet the research objectives.

\section{Research Methodology}

The first objective of this study was to develop a comprehensive instrument that could reliably assess the overall appeal of e-tailing websites. Using the theoretical framework outlined above as the guideline, a detailed review of literature was conducted in order to isolate a list of web elements that can be used to evaluate overall appeal. Secondary sources, such as scholarly publications, online blogs, books and journals on the web were scrutinized for identifying elements or attributes on a web page that signify effective web design and influence users' perception of 
appeal. In addition to this, existing websites were visually inspected to shortlist repeatedly used elements on online shopping websites that serve marketing ends. This method generated 108 elements that regularly appeared across published literature and online stores, and were, therefore, used to build the data collection instrument.

\subsection{Building the Instrument}

The initial pool of 108 web elements was analyzed in order to eliminate or merge overlapping items. The refined list of elements was reviewed again by the authors to achieve consensus in terms of clarity and completeness of the list, ultimately resulting in 63 elements. The web elements were then categorized into general and marketing mix elements, as per the 13 item schema proposed in the theoretical framework, using directed content analysis.

Directed content analysis is a systematic technique used to structure open ended data when prior research or existing theory provides key concepts to be used as the initial codes [55]. The technique requires that each element be compared against the description of the preexisting categories or codes to identify which category, in the first instance, suits the element best. In this way, all 63 elements were coded using the 13 predetermined codes. Elements that could not be categorized within the initial coding scheme were isolated and analyzed later to determine if they represented a new category or signified a subcategory of an existing code. The steps were repeated till all the elements had been placed in their respective categories. Lastly, the categorized elements were cross checked with published literature and shared with regional academics specializing in online retail to rule out any discrepancies, and to ensure content, construct, and face validity of the classification. The classification underwent several months of critique, revision, and informal pilot tests before being concluded to its final state (Table 3).

Table 3: Evaluation framework for assessing overall website appeal

\begin{tabular}{|c|c|c|}
\hline \multicolumn{3}{|c|}{ General Elements } \\
\hline Look and Feel & Credentials & Customization \\
\hline Aesthetical Elements & Management Statement & Accessibility for Disabled \\
\hline Amount of Content & Mission/Vision/History & Customization Options \\
\hline Spelling or Grammar & Contact Details & Adaptive Website \\
\hline Readability & Privacy Policy & \\
\hline Compatibility & Terms and Conditions & \\
\hline Download Time & Copyrights & \\
\hline Navigation & Content & \\
\hline Logical Organization of Pages & Necessary Information & \\
\hline Site Map / Index & Accurate Information & \\
\hline Search Engine & Regularly Updated Information & \\
\hline Broken Links & Quality of Graphics & \\
\hline Intuitive Navigation & Valuable Animations & \\
\hline \multirow{2}{*}{\multicolumn{3}{|c|}{ Marketing Mix Elements }} \\
\hline & & \\
\hline Product & Promotion & People \\
\hline Product Variety & Special Offers & Online Help \\
\hline Product Images & Online Advertisements & Customer Support \\
\hline Product Customization & Links to Offline Ads. & Email/Telephone Contacts \\
\hline Product Description & Newsletters or emails & Feedback forms \\
\hline Product Availability & Membership Benefits & Discussion Groups \\
\hline Online Purchase & Social Media & Physical Evidence \\
\hline Price & Testimonials & Brand Name \\
\hline Reasonable Prices & Process & Logo \\
\hline Discounts & Related Offers & Corporate Office/Building \\
\hline Payment Methods & Customer Focus & Overall Online Experience \\
\hline Refund Policy & Easy Order Confirmation & Partnerships/Public Relations \\
\hline Place & & Press Releases \\
\hline Delivery Options & & Awards and Accomplishments \\
\hline Delivery Time & & Career Opportunities \\
\hline Geographical Coverage & & $\begin{array}{l}\text { Charitable Events } \\
\text { Sponsorships and Affiliations }\end{array}$ \\
\hline
\end{tabular}

The 13 categories and their respective dimensions were then arranged to formulate a closed ended gird, summarizing the crux of website appeal, where each element was measured on a 5 point Likert scale (where scores close to 1 signified poor appeal, while proximity to 5 coincided with highly appealing elements). A Likert scale was chosen due to its common usage in attitude measurement [57] and because it is the preferred measurement scale when the data is intended to go through factor analysis [54]. 


\subsection{Testing the Instrument}

The next objective of the study was to assess the reliability of this instrument by using it on a sample of websites. It was decided that e-tailing websites from Middle Eastern countries should be used for assessment. This was mainly because the participants to be involved in data collection were Arab nationals and were ideally suited to act as potential customers to Middle Eastern websites due to their familiarity with the language, currency, and product types of these stores. However, it was unlikely that a sufficiently large sample of actively operating e-tailing websites could be generated from a single Middle Eastern country. Therefore, the website sample selection procedure involved two stages. First, of the 22 Middle Eastern countries, eleven countries were shortlisted using purposive sampling, where the criterion for selection was an internet penetration rate of greater than $30 \%$ (Site 1). Next, the top ten e-tailing websites of these countries were sampled by referring to the ranking issued by Alexa (Site 2). During this stage, countries with insufficient number of active e-tailing websites were dropped from the sample set. Ultimately, eight Middle Eastern countries formed part of this study, namely; Kingdom of Saudi Arabia (KSA), Bahrain, Kuwait, Jordan, United Arab Emirates (UAE), Qatar, Egypt, and Lebanon.

To proceed with data collection, a team of 16 participants, residing in the UAE, was formed to take part in this study. All participants reported themselves to be proficient in common internet applications. Next, one of the eight countries was randomly assigned to two evaluators, who individually examined five of the sampled websites from that country using the website evaluation grid. The grid was presented to the participants as a highly structured self-completion questionnaire to measure overall appeal of the websites in terms of the 13 categories (and 63 elements) outlined in the grid.

Evaluators took approximately 2 hours to browse the websites and fill the questionnaire. The completed questionnaires were coded and assessed using a statistical data package, SPSS 20. Cronbach's alpha was used to determine the consistency of acquired results, whereby coefficients over 0.7 are acceptable, and coefficients greater than 0.8 are considered good [84]. The 13 items measured through the grid resulted in a Cronbach's alpha of 0.893 . Item-to- total correlations were also computed to identify internal inconsistency between elements. Considering that correlations lesser than 0.30 are weak for item analysis [29], all items in the grid indicated significant correlations with the total, indicating high levels of internal consistency. The data gathered by evaluating the 80 e-tailing websites was then used to demonstrate the usefulness of the findings generated by this tool, and to develop a conceptual framework for overall appeal.

\section{Application of the Instrument}

This section documents the usefulness of this instrument by comparing the performance of sampled websites in terms of their overall appeal, and illustrates how results derived from this instrument can help e-tailing sites better achieve their marketing objectives.

\subsection{Evaluating and Comparing Overall Appeal}

For the purpose of analysis, the data was initially subjected to descriptive statistical techniques to meaningfully summarize the information (Table 4).

Table 4: Country wise assessment of website appeal

\begin{tabular}{|l|l|l|l|l|l|l|}
\hline Country & General & Marketing Mix & Mean & S.D. & Best Aspect & Worst Aspect \\
\hline KSA & $56.00 \%$ & $56.75 \%$ & 36.7 & 3.50 & Look and Feel, Credentials & Customization \\
\hline Bahrain & $58.40 \%$ & $55.50 \%$ & 36.8 & 8.13 & Look and Feel, Navigation & Customization \\
\hline Kuwait & $60.00 \%$ & $57.25 \%$ & 37.9 & 3.28 & Look and Feel, Navigation & Customization \\
\hline Jordan & $65.60 \%$ & $54.25 \%$ & 38.1 & 7.98 & Credentials & Physical Evidence \\
\hline UAE & $60.80 \%$ & $60.00 \%$ & 39.2 & 3.05 & Navigation & Customization \\
\hline Qatar & $62.80 \%$ & $61.25 \%$ & 40.2 & 3.43 & Look and Feel & Customization \\
\hline Egypt & $61.20 \%$ & $62.50 \%$ & 40.3 & 14.92 & Navigation & Customization \\
\hline Lebanon & $78.40 \%$ & $71.50 \%$ & 48.2 & 8.59 & Navigation & Promotion \\
\hline
\end{tabular}

Average scores for each of the 13 elements were computed and cross compared amongst the eight countries. Individual scores were also summed and averaged for the ten websites of each country to rank the countries in terms of their overall performance. Since the websites were assessed on a 5 point Likert Scale, the scores ranged from 13 (lowest) to 65 (highest). As indicated in Table 4, users found Lebanon e-tailing websites to be the most 
appealing in comparison to the websites of other countries. KSA e-tailing websites received the lowest score (36.7) amongst the 8 countries, with Bahrain scoring slightly higher (36.8).

Table 4 also shows that Lebanon has the highest score in both Marketing and General web elements, and is the only country to score above $70 \%$ in either category. Jordan has received the worst score $(54.25 \%)$ in marketing mix elements while KSA has the lowest score (56.00\%) in general website elements. The table also provides further insight into these results by highlighting the variance and the best and worst aspects of the websites. Egypt, with the second highest overall score, has the highest variation amongst individual websites, while UAE demonstrated the most consistent result. Even though, Lebanon scored the highest amongst all the other countries, its Promotional schemes were rated as its poorest element. Overall, the website element that received highest ratings was Ease of Navigation, followed by Look and Feel. Websites of KSA were also appreciated for better prices and promotional schemes over the web.

These results depict the importance of this tool as a reliable and comprehensive measurement instrument that can be used to assess e-tailing websites across a range of general and marketing specific dimensions. The instrument is also able to identify the areas of strengths and weaknesses in a website, which can then be compared with the results of others competing in the same industry. It should be mentioned here that, since the instrument records user perceptions on an interval scale, the collected data can be subjected to advanced statistical techniques to suit the decision needs of the evaluator.

\subsection{Developing a Conceptual Framework}

In order to develop a conceptual framework to align elements of web appeal to e-marketing objectives, Exploratory Factor Analysis (EFA) was performed on the 13 dimensions of appeal identified in the theoretical framework. The EFA was conducted using Varimax rotation, with the number of factors reduced to four. The rotated component matrix thus generated is provided below (Table 5), illustrating the categorization of the 13 elements into four factors.

Table 5: Rotated component matrix

\begin{tabular}{|l|l|l|l|l|}
\hline \multirow{2}{*}{} & \multicolumn{4}{l}{ Component } \\
\cline { 2 - 5 } & $\mathbf{1}$ & $\mathbf{2}$ & $\mathbf{3}$ & $\mathbf{4}$ \\
\hline Place & .879 & & & \\
\hline Physical Evidence & .839 & & & \\
\hline Partnerships & .623 & & & \\
\hline People & .620 & & & \\
\hline Promotion & & .833 & & \\
\hline Price & & .798 & & \\
\hline Process & & .732 & & \\
\hline Product & & & .812 & \\
\hline Customization & & & .706 & \\
\hline Content & & & .636 & \\
\hline Look and Feel & & & & .842 \\
\hline Navigation & & & & .797 \\
\hline Credentials & & & & .601 \\
\hline
\end{tabular}

To have any value, it is important that the factors generated by EFA are labeled and interpreted in a manner that is consistent with reason and theory [129]. However, labeling the factors and assigning them themes is a subjective and inductive process [98], and the meaningfulness of the factors, and any frameworks developed using them, depends on how well a researcher defines these factors [52]. The authors' interpretation of the results is graphically illustrated in Figure 2 and discussed in the following paragraphs. The interpretation should be taken as an attempt to develop a conceptual model for website appeal, which is open for further research and confirmatory analysis.

The four factors have been labeled Attract, Engage, Compete, and Retain. These are arranged into four quadrants with respect to two evaluative dimensions; Overall Appeal (vertical axis) and Marketing Perspective (horizontal axis). The term overall appeal refers to the favorableness of the image created by the website. Websites may range from creating a good first impression to establishing a strong and lasting impression. Marketing perspective indicates the marketing philosophy of the organization, and is characterized here into two types; the basic (or traditional) seller philosophy (Quadrant 1 and 2), and relational perspective which emphasizes customer relationships (Quadrant 3 and 4). It is proposed that, when making use of this model, websites would ideally need to move from the first quadrant to the fourth quadrant in order to fulfill their objectives by maintaining an appealing website. 


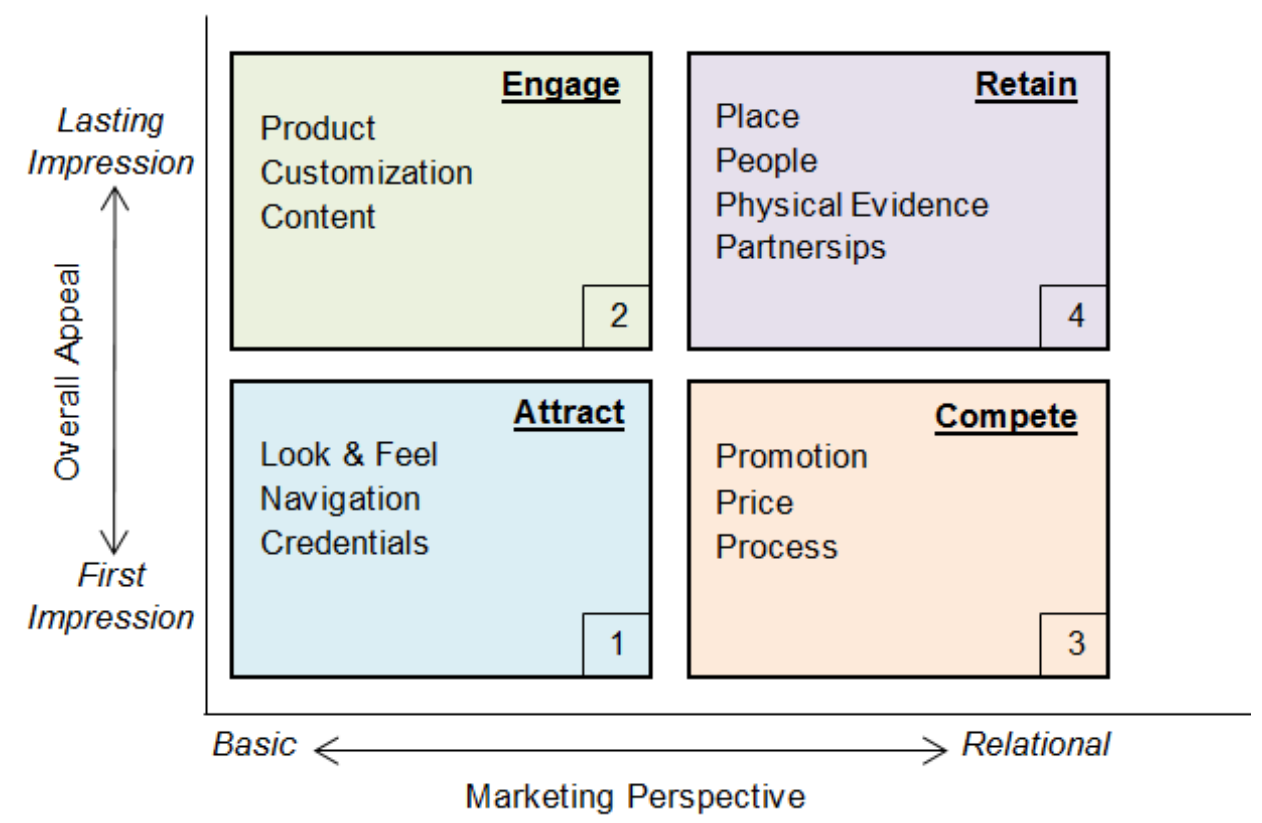

Figure 2: Website attributes assessing overall appeal

Look \& Feel, Credentials, and Navigation are the three elements in the first quadrant (Attract), which primarily work towards attracting customers by developing interest in the website. These elements are in league with the basic marketing perspective and can be optimized by e-marketers to create a good first impression of the website. However, in order to further online transactions, elements from Quadrant 2 (Engage) need to be incorporated into emarketing strategies. It is proposed here that excellence in attributes of Product, Page Content and Customization (Personalization) can translate a good first impression into a viable long lasting one. When the firm intends to follow the Relational perspective, elements from Quadrant 3 (Compete) are essential to elevate the first impression. This quadrant encompasses elements on the basis of which firms can compete with rival websites and gain an edge. Lastly, effective customer services, distribution strategy, brand image, and partnerships (public relations) are all promising ways to maintain a loyal customer base. By focusing on elements in the fourth Quadrant (Retain), relational marketers can transform a remarkable first impression into a lasting one.

For illustrative purposes, three websites were selected from our sample to be plotted on this model. As depicted in Figure 3, website A appears to be doing well in all four quadrants. The model signifies that the website has the capacity to attract, engage, and retain a loyal customer base and also has the ability to compete with rival stores. Similarly, it can be seen that website B and C are equally good at attracting customers and competing for sales, and therefore, have the ability to maintain a good first impression.

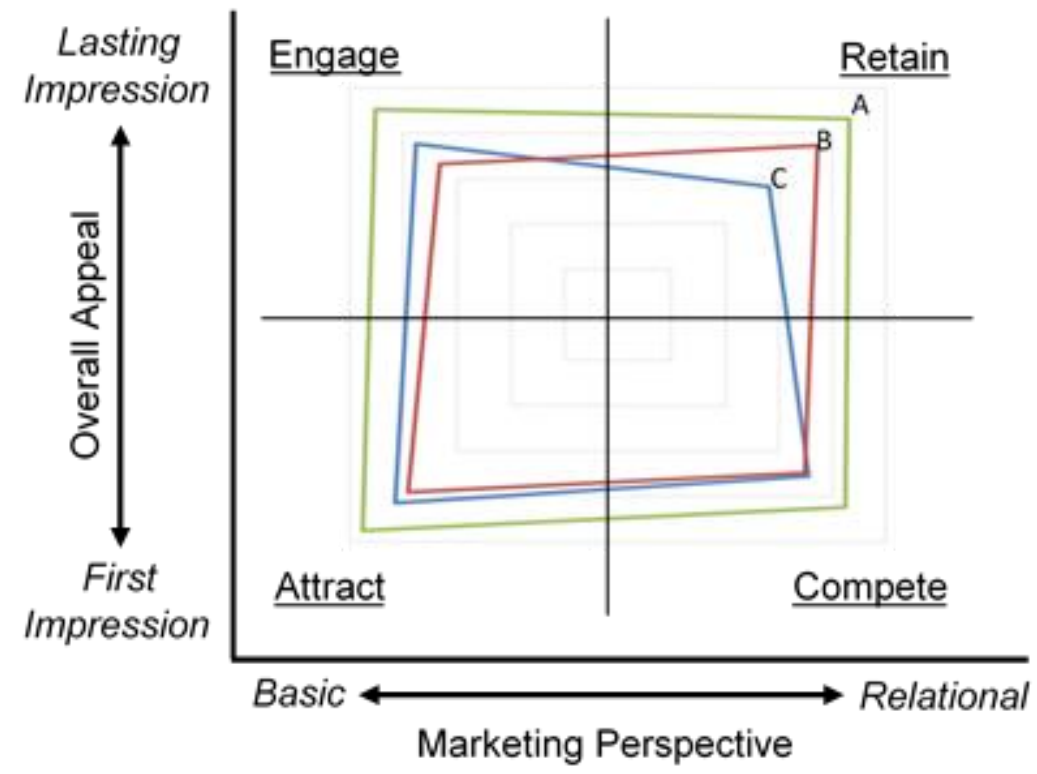

Website A

Website B

Website C

Figure 3: Comparing three websites 
However, these websites may have trouble converting the good first impression into a lasting impression, because of their lower scores in quadrants 2 and 4 respectively. Website B is significantly better at retaining its existing customers; therefore, we can infer that it is following a relational approach to marketing. The store's low score in quadrant 2 indicates that the website may have a problem with engaging new customers on the website. Therefore, recommended future actions for website B would be to work on improving the content and customization options on the website, and providing a more diverse product range. Similarly, website $\mathrm{C}$ should focus on customer service, product delivery, and partnerships, in order to improve customer retention.

Thus, by relating website appeal with marketing objectives, the framework highlights major strengths and weaknesses of websites and indicates marketing objectives that deserve more attention to enhance an e-store's web presence. Moreover, e-stores can also identify which aspects of their websites need to be improved in order to achieve their desired marketing objectives.

In the following section, the results of the current study are discussed in light of existing literature to demonstrate the theoretical soundness and practical relevance of the presented model.

\section{Discussion}

Aesthetics and visual elements are certainly the aspects of website appeal that have received the most attention in publications, whereby several authors have developed strategies and guidelines to create a good first impression by designing appealing websites. The aim of this study was to go beyond visual aspects when defining and evaluating overall website appeal. The assessment instrument developed towards this end combined both IS and marketing elements. The tool also incorporates sub dimensions that target technical, communicative, relational, and persuasive aspects of a website, considered essential for all models assessing websites [39].

The conceptual model proposed here makes an attempt at explaining how a website's good first impression can be transformed into a long lasting one. This is done by aligning essential website attributes found on e-stores with the four main objectives of digital marketers; attract, engage, compete, and retain; relating it with existing work [64], [108]. As is suggested by the present model, Ganesh et al. [41] has indicated that interesting web pages have the ability to motivate users towards shopping online. The model also emphasizes the significance of a relational approach to marketing when the firm aims to achieve competitive advantage and maintain a loyal customer base, while emphasis on attracting and engaging customers is usually concurrent with the traditional (basic) marketing philosophy [9], [25], [42].

Website attributes that were assigned to the four marketing objectives (quadrants) also gain theoretical backing from the findings in existing literature. For instance, the proposed framework associates the e-marketing objective of attracting users with elements of look and feel, navigation, and credibility. As noted in the literature review, several authors have identified look and feel to be the prime website attribute that attracts the customers' attention on a website. Findings of Thielsch and Hirschfeld [114] also support this affiliation by recording the role of effective navigation in attracting users. In a similar context, Albert et al. [2] and Fogg et al. [40] identify the importance of credibility of a website in attracting users' interest in an e-store. These elements have also been linked to creating a good first impression on the store [76], [88]. Moreover, the model suggests that aesthetic elements are not the only determinants in establishing a favorable first impression. This observation has also been made by Papachristos and Avouris [93], who note that immediate impression about websites does not just influence perceptions of attractiveness.

In the same way, matching the model's elements in the second quadrant (compete), e-tailers' strategy to compete for new and existing customers using promotion and pricing strategies has been noted in the literature [56]. The objective of engaging customers and positively influencing their shopping intentions on e-stores has been related with product assortment [58] and informational content on e-stores [100]. The ability to customize the online purchase process has also been associated with improving customer satisfaction and generating positive behavioral consequences [115]. This is in line with the categorization of elements in quadrant 3 (engage). Lastly, when identifying factors affecting likelihood to buy again from a given merchant, customer support and on time delivery were found to be most influential [102]. This is supported by the model presented here that aligns the elements of Place and People with the marketing objective of retaining customers. Issues such as timely delivery (place) are considered essential determinants of e-service quality [132]. As Jiang and Rsenbloom [60] assert, economy and flexibility of shipping can have a significant and positive effect on a customer's intention to return to the site.

Due to the extremely limited research work done on the evaluation of Middle Eastern websites, it has not been possible to extensively compare the country-specific findings generated using this tool with those in the literature. However, one major contradiction was noted. Studies that have assessed local e-commerce websites in Arab countries have mostly noted the inability of e-stores to meet acceptable standards of credibility [3], [5], [51], [107]. For instance, Al-Ghaith et al. [3] identify e-trust and privacy issues as the reason for low adoption of e-services in KSA. The present evaluation of e-tailing websites does not match these results. This contradiction in findings may have resulted due to the fact that the present study only assessed the highest ranking websites in the region which appeared to be sufficiently credible. It is also possible that the sampled websites may have undergone design 
improvements since the last time they were evaluated, suggesting that the credibility issues of Middle Eastern websites are no longer a critical problem.

\section{Limitations and Future Research}

Although the evaluation instrument proposed in this paper allows for comprehensive assessment of e-tailing websites, the categorization of the web elements, and the taxonomy used to describe them, is essentially based on the understanding and the experience of the authors, and is open to deliberation by others. It is recommended that the assessment tool be evaluated in a variety of settings to confirm its reliability, sensitivity, and ease of use. Moreover, given the exploratory nature of this research, testing of specific hypotheses based on the proposed model remained outside the scope of this study. It should be noted here, however, that future researchers making use of this instrument can quantitatively examine websites and subject their findings to advanced inferential statistical techniques because the instrument is composed of multiple dimensions that are measured on an interval scale.

A major concern of this study was to define the concept of web appeal beyond aesthetic elements and relate it to emarketing effectiveness. To develop a comprehensive measure, dimensions from the fields of IS and e-marketing were compiled from both theory and practice to construct the theoretical framework. However, as is mostly the case in social sciences, the theoretical framework does not account for interdependency or causal relationships that may exist between the elements defined. A next step towards advancing the findings of this study could be to relate the concept of web appeal to other aspects of consumer perceptions and assess how overall web appeal influences a buyer's purchase behavior over the web.

Moreover, due to the dynamic nature of websites, assessment of e-stores done using this instrument would also need to be continuously updated to hold relevance in the long run. Given that this is an inherent limitation in most studies centering on the World Wide Web, with consistency, such studies can lead to time series analyses that document online shopping trends and evolutions in the field of e-marketing.

This study also specifically concentrated on evaluating the highest ranking websites of each country, thereby identifying some of the best practices adopted by e-tailers in the region. This nullifies the scope for generalization and, therefore, the country-specific results of this study should not be inferred beyond the context in which they have been discussed here. Future investigators may aim to use this instrument in a broader context and on larger samples to generate nationwide indices. By assessing web appeal of a representative sample of websites, researchers can also associate their findings with common internet usage statistics to better understand a country's technology acceptance and internet adoption measures.

\section{Conclusion and Implications}

The aim of this study was to develop a comprehensive measure of a web store's appeal to aid e-marketers, as well as to contribute to the theoretical body of knowledge focusing on evaluating e-marketing effectiveness. Using cues from published literature and by reviewing existing e-tailing sites, a hybrid approach to website assessment was adopted that identified both IS (look and feel, navigation, credentials, content, and customization) and marketing (product, price, place, promotion, people, process, physical evidence, and partnership) dimensions to build this instrument. The instrument's validity was confirmed by testing it across 80 e-stores in the Middle East and its usefulness as a measure of web appeal was established.

The results of the assessment suggested that leading e-stores in the region still need to improve their customization tools, while they appear to do well in the areas of usability and visual appeal.

This study also proposes a conceptual model that can record users' perceptions on overall appeal and help e-tailers assess the effectiveness of their e-marketing endeavors in terms of these perceptions. An illustration of this model evaluating a set of websites was used to demonstrate its practical relevance to those involved in online marketing, and its theoretical soundness was judged by reviewing its four components (attract, engage, compete, and retain) in light of existing literature.

Since digital mediums do not have the advantage of physically reaching out to its audience, losing a potential customer is literally just one click away. The findings of this study hold practical implications for web practitioners and e-marketers. The proposed assessment instrument and the supporting conceptual model can help web design experts and e-marketers to identify the strengths and weaknesses of their websites. E-stores can quantify the overall appeal of their websites and compare their scores with those of the competitors or established benchmarks to guide future performance and remedy existing flaws.

Additionally, given the ubiquitous nature of marketing principles, the implications of the model presented here can easily be extended beyond e-tailing sites to all firms maintaining an online presence. E-marketing professionals, regardless of the nature of the firm, can adapt the dimensions proposed in this study to meet the requirements of their websites and use the framework to develop future marketing strategies and enhance their websites' overall 
appeal. E-marketers should also make use of this model to attest whether their sites' web attributes align well with the marketing objectives they set to achieve.

As a whole, this study adds to the theoretical realm of e-commerce, in particular the e-marketing literature, by proposing a conceptual framework that aligns elements of website appeal to e-marketing objectives. The model provides a systematic criteria for comparing websites, and offers valuable insight into how website attributes can be used to achieve desired performance in terms of attracting, engaging, and retaining customers, as well competing with rival stores. It is believed that by basing actionable decisions on the criteria defined in this model, e-marketers and web practitioners would be able to design e-stores with a good first impression, and will also be able to successfully transform the pleasant first impression into a long-lasting one.

\section{Acknowledgments}

The authors would like to thank the reviewers for taking the time to assess this paper and for providing valuable critique; their suggestions and guidelines have helped us in improving this work's clarity and consistency. A sincere note of appreciation also goes out to the experts who willingly provided valuable and timely feedback for editing the research instrument.

\section{Websites List}

Site 1: Internet World Stats: Usage and Population Statistics http://www.internetworldstats.com/stats.htm

Site 2: Alexa - Actionable Analytics for the Web http://www.alexa.com/

\section{References}

[1] A. Akincilar and M. Dagdeviren, A hybrid multi-criteria decision making model to evaluate hotel websites, International Journal of Hospitality Management, vol. 36, pp. 263-271, 2014.

[2] W. Albert, W. Gribbons, and J. Almadas, Pre-conscious assessment of trust: A case study of financial and health care web sites, in Proceedings of the Human Factors and Ergonomics Society Annual Meeting, San Antonio, 2009, pp. 449-453.

[3] W. Al-Ghaith, L. Sanzogni, and K. Sandhu, Factors influencing the adoption and usage of online services in Saudi Arabia, The Electronic Journal on Information Systems in Developing Countries, vol. 40, no. 1, pp.1-32, 2010.

[4] V. Badrinarayanan, E.P. Becerra, and S. Madhavaram, Influence of congruity in store-attribute dimensions and self-image on purchase intentions in online stores of multichannel retailers, Journal of Retailing and Consumer Services, vol. 21, no. 6, pp. 1013-1020, 2014.

[5] A.A. Bahaddad, L. Houghton and S. Drew, Attracting customer in Saudi Arabia to buy from your business online, International Journal of Business and Management, vol. 8, no. 7, pp. 65-81, 2013.

[6] D. Baier and E. Stüber, Acceptance of recommendations to buy in online retailing, Journal of Retailing and Consumer Services, vol. 17, no. 3, pp. 173-180, 2010.

[7] G. Balabanis and N.L. Reynolds, Consumer attitudes toward multi-channel retailers' websites: The role of environment, brand attitude, internet knowledge, and visit duration, Journal of Business Strategies, vol. 18, no. 2, pp. 105-131, 2001.

[8] C. Bèzes, Definition and psychometric validation of a measurement index common to website and store images, Journal of Business Research, vol. 67, no. 12, pp. 2559-2578, 2014.

[9] N. Bickhoff, S. Hollensen and M. Opresnik, Marketing and marketing management: A first basic understanding, in The Quintessence of Marketing (N. Bikhoff, Ed.). Berlin: Springer Berlin Heidelberg, 2014, pp. 3-15.

[10] B.F. Blake and K.A. Neuendorf, Cross-national differences in website appeal: A framework for assessment, Journal of Computer-Mediated Communication, vol. 9, no. 4, 2004.

[11] B.F. Blake, K.A. Neuendorf, and C.M. Valdiserri, Tailoring new websites to appeal to those most likely to shop online, Technovation, vol. 25, no. 10, pp. 1205-1214, 2005.

[12] N. Bonnardel, A. Piolat, and L. Le Bigot, The impact of color on website appeal and users' cognitive processes, Displays, vol. 32, no. 2, pp. 69-80, 2011.

[13] B. Booms and M. Bitner, Marketing strategies and organization structures for service firms, in Proceedings Marketing of Services: Special Educators' Conference, Chicago, 1981, pp. 46-51.

[14] T.J. Brown and P.A. Dacin, The company and the product: Corporate associations and consumer product responses, Journal of Marketing, vol. 61, no. 1, pp. 68-84, 1997.

[15] L. Burgess and J. Cooper, Extending the viability of MICA (model of internet commerce adoption) as a metric for explaining the process of business adoption of internet commerce, presented at the International Conference on Telecommunications and Electronic Commerce, Dallas, November 16-19, 2000.

[16] X. Cao, The relationships between e-shopping and store shopping in the shopping process of search goods, Transportation Research Part A: Policy and Practice, vol. 46, no. 7, pp. 993-1002, 2012. 
[17] S. Cebi, A quality evaluation model for the design quality of online shopping websites, Electronic Commerce Research and Applications, vol. 12, no. 2, pp. 124-135, 2013

[18] D. Chaffey and P.R. Smith, E-marketing eXcellence: Planning and Optimizing your Digital Marketing. Burlington: Butterworth-Heinemann, 2008.

[19] D. Chaffey, F. Chadwick, K. Johnston, and R. Mayer, Internet Marketing - Strategy Implementation and Practice. Harlow: Prentice Hall, 2006.

[20] H.H. Chang and H. Wang, The moderating effect of customer perceived value on online shopping behavior, Online Information Review, vol. 35, no. 3, pp.333-359, 2011

[21] T. Chikweche and R. Fletcher, Customer relationship management at the base of the pyramid: myth or reality?, Journal of Consumer Marketing, vol. 30, no. 3, pp. 295-309, 2013

[22] W. Chiou, C. Lin, and C. Perng, A strategic framework for website evaluation based on a review of the literature from 1995-2006, Information and Management, vol. 47, no. 5-6, pp. 282-290, 2010.

[23] W.K. Chong, M. Shafaghi, C. Woollaston, and V. Lui, B2B e-marketplace: An e-marketing framework for B2B commerce, Marketing Intelligence and Planning, vol. 28, no. 3, pp. 310-329, 2010.

[24] J. Collier and C. Bienstock, A conceptual framework for measuring e-service quality, in Proceedings of the Developments in Marketing Science, Academy of Marketing Science, Corel Gables, FL, 2003, pp. 158-162.

[25] E. Constantinides, The 4S web-marketing mix model, Electronic Commerce Research and Applications, vol. 1, no. 1, pp. 57-76, 2002.

[26] M. Dahlen, A. Rasch, and S. Rosengren, Love at first site? A study of website advertising effectiveness, Journal of Advertising Research, vol. 43, no. 1, pp. 25-33, 2003.

[27] R. Darby, J. Jones, and G. Al Madani, E-commerce marketing: fad or fiction? Management competency in mastering emerging technology. An international case analysis in the UAE, Logistics Information Management, vol. 16, no. 2, pp. 106-113, 2003.

[28] A. de Angeli, A. Sutclie, and J. Hartmann, Interaction, usability and aesthetics: What influences users' preferences?, in Proceedings of the 6th ACM conference on Designing Interactive Systems, New York, 2006, pp. 271-280.

[29] D. de Vaus, Surveys in Social Research. London: Routledge, 2002.

[30] W.D. DeLone and E.R. McLean, The DeLone and McLean model of information systems success: A ten-year update, Journal of Management Information Systems, vol. 9, no. 1, pp. 9-30, 2003.

[31] R.R. Dholakia and M. Zhao, Effects of online store attributes on customer satisfaction and repurchase intentions, International Journal of Retail and Distribution Management, vol. 38, no. 7, pp. 482-496, 2010.

[32] E. Díaz and C. Koutra, Evaluation of the persuasive features of hotel chains websites: A latent class segmentation analysis, International Journal of Hospitality Management, vol. 34, pp. 338-347, 2013.

[33] A. Dickinger and B. Stangl, Website performance and behavioral consequences: A formative measurement approach, Journal of Business Research, vol. 66, no. 6, pp. 771-777, 2013.

[34] R. Eid and M. Treman, Factors affecting the success of business-to-business international internet marketing: An empirical study of UK companies, Journal of Industrial Management and Data System, vol. 104, no. 1, pp. 16-30, 2004.

[35] N. Elkhani, S. Soltani, and M.H.M. Jamshidi, Examining a hybrid model for e-satisfaction and e-loyalty to eticketing on airline websites, Journal of Air Transport Management, vol. 37, pp. 36-44, 2014.

[36] Y. Eri, M.A. Islam, and K.A.K. Daud, Factors that influence customers' buying intention on shopping online, International Journal of Marketing Studies, vol. 3, no. 1, pp. 128-139, 2011.

[37] A. Everard and D. Galletta, How presentation flaws affect perceived site quality, trust, and intention to purchase from an online store, Journal of Management Information Systems, vol. 22, no. 3, pp. 55-95, 2006

[38] X. Fang and C.W. Holsapple, An empirical study of web site navigation structures' impacts on web site usability, Decision Support Systems, vol. 43, no. 2, pp. 476-491, 2007.

[39] J. Fernández-Cavia, C. Rovira, P. Díaz-Luque, and V. Cavaller, Web quality index (WQI) for official tourist destination websites. Proposal for an assessment system, Tourism Management Perspectives, vol. 9, pp. 5-13, 2014

[40] B.J. Fogg, C. Soohoo, D.R. Danielson, L. Marable, J. Stanford, and E.R. Tauber, How do users evaluate the credibility of Websites? A study with over 2500 participants, in Proceedings Association for Computing Machinery Proceedings of the Conference on Designing for User Experiences, New York, 2003, pp. 1-15.

[41] J. Ganesh, K.E. Reynolds, M. Luckett, and N. Pomirleanu, Online shopper motivations, and e-store attributes: An examination of online patronage behavior and shopper typologies, Journal of Retailing, vol. 86, no. 1, pp. 106-115, 2010.

[42] C. Gronroos, From marketing mix to relationship marketing - towards a paradigm shift in marketing, Management Decision vol. 34, no. 5, pp. 322-339, 1997.

[43] Y. Guo and G. Salvendy, The factor structure of content preparation for e-business websites: Results of a survey of 428 industrial employees in the People's Republic of China, Journal of Behavior and Information Technology, vol. 28, no. 1, pp. 73-86, 2009

[44] S. Guo, M. Wang, and J. Leskovec, The role of social networks in online shopping: Information passing, price of trust, and consumer choice, in Proceedings of the 12th ACM Conference on Electronic Commerce, New York, 2011, pp. 157-166.

[45] C. Gurau, Integrated online marketing communication: Implementation and management, Journal of Communication Management, vol. 12, no. 2, pp. 169-184, 2008.

[46] R. Hall and P. Hanna, The impact of web page text-background color combinations on readability, retention, aesthetics, and behavioral intention, Behavior and Information Technology, vol. 23, no. 3, pp. 183-195, 2004. 
[47] R. Hansen and N. Bjørn-Andersen, Cube assessment framework for B2C websites applied in a longitudinal study in the luxury fashion industry, Journal of Theoretical and Applied Electronic Commerce Research, vol. 8, no. 2, pp. 1-20, 2013.

[48] L. Hasan and E. Abuelrub, Assessing the quality of web sites, Applied Computing and Informatics, vol. 9, no. 1, pp. 11-29, 2011

[49] J.P. Hasley and D.G. Gregg, An exploratory study of website information content, Journal of Theoretical and Applied Electronic Commerce Research, vol. 5, no. 3, pp. 27-38, 2010.

[50] M. Hassenzahl and A. Monk, The inference of perceived usability from beauty, Human-Computer Interaction, vol. 25, no. 3, pp. 235-260, 2010.

[51] T.F. Henari and R. Mahboob, E-commerce in Bahrain: the non-technical limitation, Education, Business and Society: Contemporary Middle Eastern Issues, vol. 1, no. 3, pp. 213-220, 2008.

[52] R.K. Henson and J.K. Roberts, Use of exploratory factor analysis in published research: common errors and some comment on improved practice, Educational and Psychological Measurement, vol. 66, no. 3, pp. 393-416, 2006.

[53] D.L. Hoffman and T.P. Novak, How to acquire customers on the web, Harvard Business Review, vol. 78, no. 3, pp. 179-188, 2000.

[54] D. Hooper, Exploratory Factor Analysis, in Approaches to Quantitative Research - Theory and its Practical Application: A Guide to Dissertation Students (H. Chen, Ed.). Cork, Ireland: Oak Tree Press, 2012, pp. 1-32.

[55] H. Hsieh and S.E. Shannon, Three approaches to qualitative content analysis, Qualitative Health Research, vol. 15, no. 9, pp. 1277-1288, 2005.

[56] Y. Huang, S. Chen, and J. Hob, A study on pricing and delivery strategy for e-retailing systems, Transportation Research Part E: Logistics and Transportation Review, vol. 59 (C), pp. 71-84, 2013.

[57] S. Jamieson, Likert scales: how to (ab)use them, Medical Education, vol. 38, no. 12, pp. 1212-1218, 2004.

[58] S.L. Jarvenpaa and P. Todd, Consumer reactions to electronic shopping on the world wide web, International Journal of Electronic Commerce, vol. 1, no. 2, pp. 59-88, 1997.

[59] B.J. Jaworski and J.F. Rayport, E-Commerce. New York: McGraw-Hill Higher Education, 2000

[60] P. Jiang and B. Rosenbloom, Customer intention to return online: price perception, attribute-level performance, and satisfaction unfolding over time, European Journal of Marketing, vol. 39, no. 1/2, pp. 150-174, 2005.

[61] K. Kalyanam and S. Mclntyre, The e-marketing mix: a contribution of the e-tailing wars, Journal of Marketing Science, vol. 30, no. 4, pp. 483-495, 2002.

[62] K. Karvonen, L. Cardholm, and S. Karlsson, Cultures of trust: A cross-cultural study on the formation of trust in an electronic environment, in Proceedings of the Nordic Workshop on Secure IT Systems, Reykjavik, Iceland, 2000, pp. 89-100.

[63] M.Y. Kiang, T.S. Raghu, and K.H. Shang, Marketing on the internet - who can benefit from an online marketing approach? Decision Support Systems, vol. 27, no. 4, pp. 383-393, 2000.

[64] A. Kierzkowski, S. McQuade, R. Waitman, and M. Zeisser, Marketing to the digital consumer, The McKinsey Quarterly, vol. 33, no. 3, pp. 5-21, 1996.

[65] H. Kim and D. Fesenmaier, Persuasive design of destination web sites: An analysis of first impression, Journal of Travel Research, vol. 47, no. 1, pp. 3-13, 2008.

[66] M. Kim, N. Chung and C. Lee, The effect of perceived trust on electronic commerce: Shopping online for tourism products and services in South Korea, Tourism Management, vol. 32, no. 2, pp. 256-265, 2011

[67] P. Kotler and W. Mindak, Marketing and public relations, Journal of Marketing, vol. 42, no. 4, pp.13-20, 1978.

[68] S.U. Kucuk, Towards integrated e-marketing value creation process, Journal of Direct, Data and Digital Marketing Practice, vol. 12, no. 4, pp. 345-363, 2011

[69] B. Lauterborn, New marketing litany: four Ps passe': C-words take over, Advertising Age, vol. 61, no. 41, p. 26, 1990.

[70] S. Lee and R.J. Koubek, Understanding user preferences based on usability and aesthetics before and after actual use, Interacting with Computers, vol. 22, no. 6, pp. 530-543, 2010.

[71] J. Lee, D. Park, and I. Han, The different effects of online consumer reviews on consumers' purchase intentions depending on trust in online shopping malls: An advertising perspective, Internet Research, vol. 21, no. 2, pp.187-206, 2011.

[72] P.S.H. Leeflang, P.C. Verhoef, P. Dahlström, and T. Freundt, Challenges and solutions for marketing in a digital era, European Management Journal, vol. 32, no. 1, pp. 1-12, 2014.

[73] T. Li and Z. Meshkova, Examining the impact of rich media on consumer willingness to pay in online stores, Electronic Commerce Research and Applications, vol. 12, no.6, pp. 449-461, 2013.

[74] D. Lin, Z. Zhou, and X. Guo, A study of the website performance of travel agencies based on the EMICA model, Journal of Service Science and Management, vol. 2, no. 3, pp. 181-185, 2009

[75] G. Lindgaard, C. Dudek, D. Sen, L. Sumegi, and P. Noonan, An exploration of relations between visual appeal, trustworthiness and perceived usability of homepages, ACM Transactions on Computer-Human Interaction, vol. 18, no.1, pp. 1-30, 2011.

[76] G. Lindgaard, G. Fernandes, C. Dudek, and J. Brown, Attention web designers: you have 50 milliseconds to make a good first impression!, Behavior and Information Technology, vol. 25, no. 2, pp. 115-126, 2006.

[77] G.Z. Liu, Z.H. Liu, and G.J. Hwang, Developing multi-dimensional evaluation criteria for english learning websites with university students and professors, Computers and Education, vol. 56, no. 1, pp. 65-79, 2011.

[78] Y. Liu, H. Li, and F. Hu, Website attributes in urging online impulse purchase: An empirical investigation on consumer perceptions, Decision Support Systems, vol. 55, no. 3, pp. 829-837, 2013. 
[79] M.D. Loda, Comparing web sites: An experiment in online tourism marketing, International Journal of Business and Social Science, vol. 2, no. 22, pp. 70-78, 2011

[80] M.M. Long and L. Chiagouris, The role of credibility in shaping attitudes toward nonprofit websites, International Journal of Nonprofit and Voluntary Sector Marketing, vol. 11, no. 3, pp. 239-249, 2006.

[81] I. López and S. Ruiz, Explaining website effectiveness: The hedonic-utilitarian dual mediation hypothesis, Electronic Commerce Research and Applications, vol. 10, no. 1, pp. 49-58, 2011.

[82] C. Luna-Nevarez and M.R. Hyman, Common practices in destination website design, Journal of Destination Marketing and Management, vol. 1, no. 1-2, pp. 94-106, 2012.

[83] R.D. Lynch, R.J. Kent and S.S. Srinivasan, The global Internet shopper: Evidence from shopping tasks in 12 countries, Journal of Advertising Research, vol. 41, no. 3, pp. 15-23, 2001.

[84] N. Malhotra and D. Birks, Marketing research - An applied approach. London: Prentice Hall, 2007.

[85] E.J. McCarthy, Basic Marketing: A Managerial Approach. Homewood, IL: Richard D. Irwin, 1960.

[86] D.H. McKnight and N.L. Chervany, What trust means in e-commerce customer relationships? An interdisciplinary conceptual typology, International Journal of Electronic Commerce, vol. 6, no. 2, pp. 35-59, 2002.

[87] S.K. Meng and C. Chatwin, Measuring e-marketing mix elements for online business, International Journal of EEntrepreneurship and Innovation, vol. 3, no. 3, pp. 13-26, 2013.

[88] E. Michailidou, S. Harper and S. Bechhofer, Visual complexity and aesthetic perception of web pages, in Proceedings of SIGDOC '08. ACM, Lisbon, Portugal, 2008, pp. 215-224.

[89] S. Minocha, M. Petre, E. Tzanidou, G. van Dijk, D. Roberts, N. Gassman, N. Millard, B. Day, and D. Travis, Evaluating e-commerce environments: approaches to cross-disciplinary investigation, in Proceeding Extended Abstracts on Human Factors in Computing Systems, ACM, New York, 2006. pp. 1121-1126.

[90] K.E. Möller, Comment on: The marketing mix revisited: Towards the 21 st century marketing? by E. Constantinides, Journal of Marketing Management, vol. 22, no. 3, pp. 439-450, 2006.

[91] A. O'Cass and J. Carlson, An e-retailing assessment of perceived website-service innovativeness: Implications for website quality evaluations, trust, loyalty, and word of mouth, Australasian Marketing Journal, vol. 20, no. 1, pp. 28-36, 2012.

[92] J.W. Palmer and D.A. Griffith, An emerging model of website design for marketing, Communications of the ACM, vol. 41, no. 3, pp. 45-51, 1998.

[93] E. Papachristos and N. Avouris, Are first impressions about websites only related to visual appeal?, in Proceedings 13th IFIP TC International Conference, Lisbon, Portugal, 2011, pp. 489-496.

[94] D.V. Parboteeah, J.S. Valacich, and J.D. Wells, The influence of website characteristics on a consumer's urge to buy impulsively, Information Systems Research, vol. 20, no. 1, pp. 60-78, 2009.

[95] Y.A. Park and U. Gretzel, Success factors for destination marketing web sites: A qualitative meta-analysis, Journal of Travel Research, vol. 46, no. 1, pp. 46-63, 2007.

[96] M. Perry and C. Bodkin, Content analysis of Fortune 100 company websites, Corporate Communications: An International Journal, vol. 5, no. 2, pp.87-96, 2000.

[97] M. Petre, S. Minocha, and D. Roberts, Usability beyond the website: An empirically grounded e-commerce evaluation instrument for the total customer experience, Behavior and Information Technology, vol. 25, no. 2, pp. 189-203, 2006.

[98] M.A. Pett, N.R. Lackey, and J.J Sullivan, Making Sense of Factor Analysis: The Use of Factor Analysis for Instrument Development in Health Care Research. California: Sage Publications Inc., 2003.

[99] D. Popovic, Modelling the marketing of high-tech start-ups, Journal of Targeting, Measurement and Analysis for Marketing, vol. 14, no. 3, pp. 260-276, 2006

[100]F. Rahimnia and J.F. Hassanzadeh, The impact of website content dimension and e-trust on e-marketing effectiveness: The case of Iranian commercial saffron corporations, Information and Management, vol. 50, no. 5, pp. 240-247, 2013.

[101]C. Ranganathan and S. Ganapathy, Key dimensions of business-to-consumer web sites, Information and Management, vol. 39, no. 6, pp. 457-465, 2002.

[102]D.J. Reibstein, What attracts customers to online stores, and what keeps them coming back?, Journal of the Academy of Marketing Science, vol. 30, no. 4, pp. 465-473, 2002.

[103]K. Reinecke, T. Yeh, L. Miratrix, R. Mardiko, Y. Zhao, J. Liu, and K.Z. Gajos, Predicting users' first impressions of website aesthetics with a quantification of perceived visual complexity and colorfulness, in Proceedings of the SIGCHI Conference on Human Factors in Computing Systems, New York, 2013, pp. 2049-2058.

[104]J. Royle and A. Laing, The digital marketing skills gap: Developing a digital marketer model for the communication industries, International Journal of Information Management, vol. 34, no. 2, pp. 65-73, 2014.

[105]B. Schenkman and F. Jonsson, Aesthetics and preferences of web pages, Behavior and Information Technology, vol. 19, no. 5, pp. 367-377, 2000

[106] D.E. Schultz, Marketers: Bid farewell to strategy based on old 4Ps, Marketing News, vol. 35, no. 2, p. 7, 2001

[107]Z.K. Shalhoub, Trust, privacy, and security in electronic business: the case of the GCC countries, Information Management and Communication Security, vol. 14, no. 3, pp. 270-283, 2006.

[108]A. Sharma and J.N. Sheth, Web-based marketing: The coming revolution in marketing thought and strategy, Journal of Business Research, vol. 54, no. 7, pp. 696-702, 2004.

[109]B. Shih, C. Chen, and Z. Chen, An empirical study of an internet marketing strategy for search engine optimization, Human Factors and Ergonomics in Manufacturing and Service Industries, vol. 23, no. 6, pp. 528540, 2013. 
[110]M. Sicilia and S. Ruiz, The role of flow in web site effectiveness, Journal of Interactive Advertising, vol. 8, no. 1, pp. 33-44, 2007.

[111] S.S. Srinivasan, R. Anderson, and K. Ponnavolu, Customer loyalty in e-commerce: An exploration of its antecedents and consequences, Journal of Retailing, vol. 78, no. 1, pp. 41-50, 2002.

[112]S. Stepchenkova, L. Tang, S. Jang, A.P. Kirilenko, and A.M. Morrison, Benchmarking CVB website performance: Spatial and structural patterns, Tourism Management, vol. 31, no. 5, pp. 611-620, 2010.

[113]T.S.H. Teo, Usage and effectiveness of online marketing tools among Business-to-Consumer (B2C) firms in Singapore, International Journal of Information Management, vol. 25, no. 3, pp. 203-213, 2005.

[114]M.T. Thielsch and G. Hirschfeld, Spatial frequencies in aesthetic website evaluations - explaining how ultrarapid evaluations are formed, Ergonomics, vol. 55, no. 7, pp. 731-742, 2012.

[115] S. Thirumalai and K.K. Sinha, Customization of the online purchase process in electronic retailing and customer satisfaction: An online field study, Journal of Operations Management, vol. 29, no. 5, pp. 477-487, 2011.

[116]E. Toufaily, N.Souiden, and R. Ladhari, Consumer trust toward retail websites: Comparison between pure click and click-and-brick retailers, Journal of Retailing and Consumer Services, vol. 20, no.6, pp. 538-548, 2013.

[117]W. Tsai, W. Chou, and J. Leu, An effectiveness evaluation model for the web-based marketing of the airline industry, Expert Systems with Applications, vol. 38, no. 12, pp. 15499-15516, 2011.

[118]A. Tuch, J. Bargas-Avila, and K. Opwis, Symmetry and aesthetics in website design: It's a man's business, Computers in Human Behavior, vol. 26, no. 6, pp. 1831-1837, 2010.

[119] A. Tuch, S. Roth, K. Hornbaek, K.Opwis, and J. Bargas-Avila, Is beautiful really usable? Toward understanding the relation between usability, aesthetics, and affect in $\mathrm{HCl}$, Computers in Human Behavior, vol. 28, no. 5, pp. 1596-1607, 2012.

[120]M.J. Valos, M.T Ewing, and I.H. Powell, Practitioners prognostications on the future of online marketing, Journal of Marketing Management, vol. 26, no. 3-4, pp. 361-376, 2010.

[121] $\mathrm{H}$. van der Heijden, Factors influencing the usage of websites: The case of a generic portal in the Netherlands, Information and Management, vol. 40, no. 6, pp. 541-549, 2003.

[122] T. Verhagen and W. van Dolen, The influence of online store beliefs on consumer online impulse buying: $A$ model and empirical application, Information Management, vol. 48, no. 8, pp. 320-327, 2011.

[123] S.B. Vidrio-Baron, A.W. Luse, and A.M. Townsend, Development of a culturally-oriented website usability evaluation in Proceedings of the Fifteenth Americas Conference on Information Systems, San Francisco, pp. 17, 2009.

[124] N. Vila and I. Kuster, Consumer feelings and behaviors towards well designed websites, Information and Management, vol. 48, no. 4-5, pp. 166-177, 2011.

[125] R. Viliavian. (2011, March) Analysis of online marketing campaigns effectiveness from A to Z. Search Engine Journal Website. [Online]. Available: http://www.searchenginejournal.com/analysis-of-online-marketingcampaigns-effectiveness-from-a-to-z/28795/

[126]X. Wang and J. Liu, Usability evaluation of B2C web site, in Proceedings International Conference on Wireless Communications, Networking and Mobile Computing, Shanghai, 2007, pp. 3837-3840.

[127]J. Weisberg, D. Te'eni, and L. Arman, Past purchase and intention to purchase in e-commerce: The mediation of social presence and trust, Internet Research, vol. 21, no.1, pp. 82-96, 2011.

[128]J.D. Wells, V. Parboteeah, and J.S. Valacich, Online impulse buying: Understanding the interplay between consumer impulsiveness and website quality, Journal of the Association for Information Systems, vol. 12, no. 1, pp. 32-56, 2011.

[129]B. Williams, T. Brown, and A. Onsman, Exploratory factor analysis: A five-step guide for novices, Australasian Journal of Paramedicine, vol. 8, no. 3, pp. 1-13, 2010.

[130]W. Wu, C. Lee, C. Fu, and H. Wang, How can online store layout design and atmosphere influence consumer shopping intention on a website?, International Journal of Retail and Distribution Management, vol. 42, no. 1, pp. 4-24, 2014.

[131]C. Wymbs, Digital Marketing: The time for a new academic mayor has arrived, Journal of Marketing Education, vol.33, no. 1, pp. 93-106, 2011.

[132]Z. Yang and M. Jun, Consumer perception of e-service quality: from Internet purchaser and non-purchaser perspectives, Journal of Business Strategies, vol. 19, no. 1, pp.19-41, 2002.

[133]B. Yoo and N. Donthu, Developing a scale to measure the perceived quality of an internet shopping site (SITEQUAL), Quarterly Journal of Electronic Commerce, vol. 2, no. 1, pp. 31-47, 2001. 